\title{
ANALISIS KELAYAKAN FINANSIAL AGROINDUSTRI TEPUNG AREN (Studi Kasus Di Desa Sumberjaya Kecamatan Cihaurbeuti Kabupaten Ciamis)
}

\author{
ANALYSIS OF FINANCIAL FEASIBILITY OF AREN FLOUR AGROINDUSTRY \\ (Case Study In Sumberjaya Village, Cihaurbeuti District, Ciamis District)
}

\author{
MAYANG SANTI MULYANI ${ }^{1 *}$, DINI ROCHDIANI ${ }^{2}$, BUDI SETIA $^{1}$ \\ ${ }^{1}$ Fakultas Pertanian, Universitas Galuh \\ ${ }^{2}$ Fakultas Pertanian, Universitas Padjadjaran \\ *Email: mayangsantimulyani@gmail.com
}

\begin{abstract}
ABSTRAK
Pengolahan pohon aren menjadi tepung aren dapat menjadi peluang usaha dan sebagai alternatif untuk meningkatkan pendapatan masyarakat. Tepung aren merupakan tepung yang mempunyai peranan penting sebagai bahan pangan, karena berbagai macam makanan yang digemari masyarakat banyak yang berbahan dasar tepung aren. Melihat prospek produk tepung aren terhadap kebutuhan konsumen yang bagus, membuat usaha tersebut perlu penanganan yang tepat agar dapat berkembang dan berdaya saing tinggi. Oleh karena itu, diperlukan analisis kelayakan finansial terhadap produk agroindustri tepung aren. Dari hasil perhitungan melalui kriteria investasi diperoleh hasil NPV bernilai positif atau lebih dari nol yaitu sebesar Rp.317.396.676,68, Net B/C sebesar 2,01 lebih besar dari 1, Gross B/C sebesar 1,02 lebih besar dari 1, IRR sebesar 44\% lebih besar dari $12 \%$ yaitu tingkat suku bunga bank yang sedang berlaku, Payback Period 3 tahun. Dari sisi finansial agroindustri tepung aren layak untuk dijalankan. Analisis sensitivitas yang dilakukan dengan meningkatkan biaya pembelian aci basah sebesar 5\% dan menurunkan harga jual sebesar 5\% sangat berpegaruh terhadap usaha agroindustri tepung aren, sehingga usaha tersebut tidak layak untuk dijalankan kembali.
\end{abstract}

Kata kunci : tepung aren, analisis kelayakan finansial

\begin{abstract}
Processing of palm trees into palm flour can be a business opportunity and as an alternative to increase people's income. Palm flour is flour that has an important role as a food ingredient, because various kinds of food favored by many people are made from palm flour. Seeing the prospect of palm flour products to good consumer needs, makes this business need proper handling so that it can develop and be highly competitive. Therefore, it is necessary to analyze the financial feasibility of palm flour agro-industrial products. From the calculation results through the investment criteria, the $N P V$ results are positive or more than zero, namely $R p .317,396,676.68, N e t B$ / C is 2.01 greater than 1, Gross B / C is 1.02 greater than 1, An IRR of 44\% greater than 12\%, namely the current bank interest rate, 3 year Payback Period. From the financial side, the palm flour agro-industry is feasible to run. The sensitivity analysis carried out by increasing the purchase cost of wet aci by 5\% and reducing the selling price by 5\% greatly affects the palm flour agroindustry business, so that the business is not feasible to run again.
\end{abstract}

Key words: palm flour, financial feasibility analysis

\section{PENDAHULUAN}

Agroindustri merupakan industri

yang mengolah hasil pertanian sebagai

bahan baku atau produk akhir yang dapat meningkatkan nilai tambah pada komoditas pertanian, serta pendapatan masyarakat dan lapangan pekerjaan (Soekartawi, 2001) dalam (Agriananta, 
2018).

Salah satu komoditas pertanian yang dapat meningkatkan perekonomian dan berpotensi untuk dikembangkan yaitu pohon aren yang diolah menjadi tepung aren. Arenga pinnata atau yang biasa dikenal dengan pohon aren merupakan tumbuhan yang multifungsi, karena seluruh bagian dari tanaman ini dapat dimanfaatkan. Pohon aren mampu menghasilkan bahan industri yang sudah teruji di pasar nasional maupun internasional. Misalkan bahan baku produksi tepung aren dapat dihasilkan dari batang aren (Yusuf, 2009).

Dalam upaya meningkatkan pendapatan, agroindustri bisa menjadi alternatif. Seperti di Desa Sumberjaya Kecamatan Cihaurbeuti, Kabupaten Ciamis terdapat agroidustri tepung aren. Tepung aren merupakan tepung yang mempunyai peranan penting sebagai bahan pangan, karena berbagai macam makanan seperti cendol, kue, roti, bakso, bihun, bakmi dan lain sebagainya yang banyak digemari masyarakat berbahan dasar tepung aren.

Produk yang dihasilkan dari tepung aren terbilang menarik dan banyak diminati oleh masyarakat luas, selain sebagai jajanan pasar produk berbahan tepung aren juga dapat meningkatkan penghasilan yang cukup menjanjikan.
Dengan jumlah penduduk dan kualitas hidup yang bertambah, maka permintaan terhadap tepung aren akan meningkat. Melihat prospek produk tepung aren terhadap kebutuhan konsumen yang cukup menjanjikan, membuat usaha tersebut perlu penanganan yang tepat agar dapat berkembang dan berdaya saing tinggi. Untuk mencapai sasaran tersebut maka diperlukan analisis kelayakan finansial dengan tujuan menilai keberhasilan suatu perusahaan layak atau tidaknya untuk dijalankan dan mendapat masukan sebagai pertimbangan dalam membuat suatu keputusan.

\section{METODE PENELITIAN}

Dalam penelitian ini jenis penelitian yang digunakan yaitu metode studi kasus. Menurut Nazir (2011) metode studi kasus merupakan suatu penelitian yang bersifat mendalam mengenai karakteristik terhadap objek penelitian tertentu. dalam penelitian ini teknik yang digunakan untuk penarikan sampel yaitu secara sengaja (purposive sampling) sesuai dengan tujuan penelitian, yaitu memiliki keuntungan yang mudah cepat serta relevan.

Dalam melakukan analisis kelayakan finansial, ada beberapa indikator yang perlu dipenuhi, antara lain Net Present 
Value (NPV), Net Benefit Cost Ratio (Rasio B/C), Gross B/C, Incremental Rate of Return (IRR), Payback Period (PP) dan Analisis Sensitivitas.

a. Net Present Value (NPV)

$$
\begin{aligned}
& N P V=\sum_{i=1}^{n} N B_{i}(1+i)^{-n} \\
& \text { atau } \\
& N P V=\sum_{i=1}^{n} \frac{N B_{i}}{(1+i)^{n}} \\
& \text { atau } \\
& N P V=\sum_{i=1}^{n} \overline{B_{i}}-\overline{C_{i}}=\sum_{i=1}^{n} N \overline{B_{i}}
\end{aligned}
$$

Keterangan:

$$
\begin{array}{ll}
\mathrm{NPV} & =\text { Net Present Value } \\
\mathrm{NB} & =\text { Net benefit }=\text { Benefit }- \text { Cost } \\
\mathrm{B} & =\text { Benefit }=\text { Manfaat } \\
\mathrm{C} & =\text { Biaya Investasi }+ \text { Biaya } \\
& \text { operasional } \\
& =\text { Benefit yang telah didiskon } \\
\mathrm{i} & =\text { Diskon factor } \\
\mathrm{n} & =\text { tahun (waktu) }
\end{array}
$$

Kriteria:

$\mathrm{NPV}>0$ (nol) $\rightarrow$ usaha/proyek layak untuk dilaksanakan.

NPV $<0($ nol $) \rightarrow$ usaha/proyek tidak layak untuk dilaksanakan.

$\mathrm{NPV}=0($ nol) $\rightarrow$ usaha/proyek berada dalam keadaan BEP, dimana $\mathrm{TR}=\mathrm{TC}$ dalam bentuk present value.

\section{b. Net Benefit Cost Ratio (Net B/C)}

$$
N e t B / C=\frac{\sum_{i=1}^{n} N \overline{B_{i}}(+)}{\sum_{i=1}^{n} N \overline{B_{i}}(-)}
$$

Keterangan:

Net $\mathrm{B} / \mathrm{C}=$ Net Benefit Cost Ratio

$\mathrm{NB}(+) \quad=$ diambil dari NPV yang telah di diskon positif.

NB (-) = diambil dari NPV yang telah di diskon negatif.

Kriteria:

Net B/C > 1 (satu) berarti proyek (usaha) layak dikerjakan.

Net B/C < 1 (satu) berarti proyek tidak layak dikerjakan.

Net $\mathrm{B} / \mathrm{C}=1$ (satu) berarti $=(\mathrm{BEP})$ atau $\mathrm{TR}=\mathrm{TC}$

\section{c. Gross Benefit Cost Ratio (Gross B/C)}

$$
\text { Gross } B / C=\frac{\sum_{i=1}^{n} B(1+r)^{-n}}{\sum_{i=1}^{n} C_{i}(1+r)^{-n}}
$$

Keterangan:

$\mathrm{B}=$ benefit.

$\mathrm{C}=$ cost .

Kriteria:

Gross B/C > 1 (satu) berarti proyek (usaha) layak dikerjakan. 
Gross B/C < 1 (satu) berarti proyek tidak layak dikerjakan.

Gross B/C = 1 (satu) berarti proyek dalam keadaan BEP.

\section{d. Internal Rate of Return (IRR)}

$$
I R R=i_{1}+\frac{N P V_{1}}{\left(N P V_{1}-N P V_{2}\right)}\left(i_{2}-i_{1}\right)
$$

Keterangan:

IRR = Internal Rate of Return.

$\mathrm{i}_{1} \quad=$ tingkat discount rate yang menghasilkan $\mathrm{NPV}_{1}$.

$\mathrm{i}_{2} \quad=$ tingkat discount rate yang menghasilkan $\mathrm{NPV}_{2}$.

Kriteria:

IRR > SOCC maka proyek dikatakan layak.

IRR = SOCC berarti proyek pada BEP.

IRR < SOCC dikatakan bahwa proyek tidak layak.

\section{e. Payback Period (PP)}

$$
P P=T_{p-1}+\frac{\sum_{i=1}^{n} I i-\sum_{i=1} \bar{B}_{i c p-1}}{\bar{B}_{p}}
$$

\section{Keterangan:}

$\mathrm{PP} \quad=$ Payback Period

$\mathrm{T}_{\mathrm{p}-1} \quad=$ Tahun sebelum terdapat $\mathrm{PP}$

$\mathrm{I}_{\mathrm{i}} \quad=$ Jumlah investasi yang telah didiscount
$\mathrm{B}_{\text {icp-1 }}=$ Jumlah benefit yang telah didiscount sebelum PP

$\mathrm{B}_{\mathrm{p}} \quad=$ Jumlah benefit pada PP

Kriteria:

$P P=$ tidak layak, jika PP lambat dan lebih besar dibanding target kembalinya investasi.

$P P=$ layak, jika PP lebih cepat dan lebih kecil dibanding target kembalinya investasi.

\section{f. Analisis Sensitivitas}

Setelah menganalisis melalui kriteria investasi diatas, maka dilanjutkan dengan menganalisis sensitivitas yang berguna untuk mengkaji sejauh mana perubahan unsur-unsur dalam aspek finansial kegiatan usaha yang akan dijalankan akibat adanya keadaan yang berubah-ubah. Analisis sensitivitas dilakukan dengan melakukan skenario penurunan dan peningkatan biaya serta harga pada agroindustri tepung aren. Adapun asumsi yang digunakan dalam skenario perhitungannya yaitu dengan meningkatkan biaya pembelian bahan baku (aci aren basah) sebesar 5\% dan penurunan harga jual sebesar $5 \%$. 


\section{HASIL DAN PEMBAHASAN}

Berdasarkan perhitungan kriteria investasi yang dilakukan dalam jangka waktu selama 7 tahun dari tahun 20132019 didapatkan hasil pada Tabel 1 sebagai berikut:

\section{Tabel 1. Hasil Perhitungan Kriteria Investasi Agroindustri Tepung Aren}

\begin{tabular}{lr}
\hline \multicolumn{1}{c}{ Indikator } & \multicolumn{1}{c}{ Nilai } \\
\hline NPV & Rp.317.396.676,68 \\
Net B/C & 2,10 \\
Gross B/C & 1,02 \\
IRR & $44 \%$ \\
\hline
\end{tabular}

Hasil Perhitungan Kriteria Investasi Agroindustri Tepung Aren Indikator Nilai NPV Rp.317.396.676,68 Net B/C 2,10 Gross B/C 1,02 IRR 44\% Berdasarkan Tabel 1 dapat diketahui NPV pada Agroindustri Tepung Aren yang menunjukkan bahwa manfaat bersih yang diperoleh selama 7 tahun dari tahun 20132019 dengan tingkat diskonto $12 \%$ memperoleh nilai Rp.317.396.676,68-. Hal ini menunjukkan bahwa Agroindustri Tepung Aren layak dijalankan, karena berdasarkan kriteria NPV nilai tersebut bernilai positif atau lebih besar dari nol.

Untuk nilai Net B/C pada Agroindustri Tepung Aren 2,10

menunjukkan bahwa setiap satu satuan biaya yang dikeluarkan akan memperoleh manfaat/keuntungan $\quad 2,10 \quad$ satuan. Sedangkan untuk nilai Gross B/C yaitu 1,02 .

Hal ini menunjukkan bahwa Agroindustri Tepung Aren layak dijalankan, karena nilai tersebut lebih dari 1 sesuai dengaan kriteria penilaian investasi Net $\mathrm{B} / \mathrm{C}$ dan Gross $\mathrm{B} / \mathrm{C}$. Sementara itu, untuk nilai IRR atau pengembalian dari investasi yang ditanam pada Agroindustri Tepung Aren memperoleh nilai 44\%. Hal ini menunjukan bahwa usaha tersebut layak dijalankan, karena berdasar kriteria penilaian investasi IRR nilai tersebut jumlahnya lebih besar dari nilai tingkat diskonto yang ditentukan yaitu $12 \%$.

Nilai Payback Period (PP) atau kembalinya seluruh biaya investasi yang dikeluarkan oleh Agroindustri Tepung Aren yaitu dapat dikembalikan pada tahun ke 3. Hal ini menunjukkan bahwa usaha Agroindustri Tepung Aren layak dijalankan, karena nilai Payback Period (PP) lebih kecil dari umur usaha sampai saat ini. 
Tabel 2. Hasil Perhitungan Kriteria Investasi Agroindustri Tepung Aren Apabila Harga Aci Aren Basah Naik 5\%

\begin{tabular}{lr}
\hline \multicolumn{1}{c}{ Indikator } & \multicolumn{2}{c}{ Nilai } \\
\hline NPV & Rp.-250.335.050,32 \\
Net B/C & 0,37 \\
Gross B/C & 0,98 \\
\hline \multicolumn{2}{c}{ Dari data tabel 2 dapat diketahui } \\
bahwa NPV pada Agroindustri & Tepung \\
Aren & memperoleh nilai
\end{tabular}

Aren memperoleh nilai Rp.250.335.050,32 -. Hal ini menunjukkan bahwa Agroindustri Tepung Aren tidak layak dijalankan, karena berdasarkan kriteria NPV nilai tersebut bernilai negatif atau lebih kecil dari nol.

Untuk nilai Net B/C pada Agroindustri Tepung Aren 0,37 menunjukkan bahwa setiap satu satuan biaya yang dikeluarkan akan memperoleh manfaat/keuntungan $\quad 0,37 \quad$ satuan. Sedangkan untuk nilai Gross B/C yaitu 0,98. Hal ini menunjukkan bahwa Agroindustri Tepung Aren tidak layak dijalankan, karena nilai tersebut kurang dari 1 sesuai dengan kriteria penilaian investasi Net B/C dan Gross B/C.

Tabel 3. Hasil Perhitungan Kriteria Investasi Agroindustri Tepung Aren Apabila Harga Jual Turun $5 \%$

\begin{tabular}{lr}
\hline \multicolumn{1}{c}{ Indikator } & \multicolumn{1}{c}{ Nilai } \\
\hline NPV & Rp.-363.881.395,72 \\
Net B/C & 0,20 \\
Gross B/C & 0,97 \\
\hline
\end{tabular}

Dari data tabel 3 dapat diketahui bahwa NPV pada Agroindustri Tepung Aren memperoleh nilai Rp363.881.395,72-. Hal ini menunjukkan bahwa Agroindustri Tepung Aren tidak layak dijalankan, karena berdasarkan kriteria NPV nilai tersebut bernilai negatif atau lebih kecil dari nol.

Untuk nilai Net $B / C$ pada Agroindustri Tepung Aren sebesar 0,20, sedangkan untuk nilai Gross B/C yaitu sebesar 0,97. Hal ini menunjukkan bahwa Agroindustri Tepung Aren tidak layak dijalankan, karena nilai tersebut kurang dari 1.

\section{KESIMPULAN}

Hasil dari perhitungan melalui kriteria investasi pada kelayakan finansial diperoleh hasil NPV bernilai positif atau lebih dari nol yaitu sebesar Rp.317.396.676,68, Net B/C sebesar 2,01 lebih besar dari 1, Gross B/C sebesar 1,02 lebih besar dari 1, IRR sebesar $44 \%$ lebih besar dari $12 \%$ yaitu tingkat suku bunga bank yang sedang berlaku, Payback Period 3 tahun. Dari sisi finansial agroindustri tepung aren layak untuk dijalankan.

Analisis sensitivitas yang dilakukan dengan meningkatkan biaya pembelian aci basah sebesar 5\% dan menurunkan harga jual sebesar 5\% sangat berpegaruh 
terhadap usaha agroindustri tepung aren sehingga usaha ini tidak layak untuk dijaalankan kembali

\section{DAFTAR PUSTAKA}

Afiyah, Abidatul. 2015. Analisis Studi Kelayakan Usaha Pendirian Home Industry Coklat "Cozy" Kadamengan Blitar. Jurnal Administrasi Bisnis. Vol 23 (1): 111.

Anwar, M Safrizal. 2018. Analisis Kelayakan Finansial Usaha Pembibitan Lada Di Desa Sukadana Baru Kecamatan Marga Tiga Kabupaten Lampung Timur. Vol 6 (2): 110-116.

Apandi, Yusuf. 2009. Aren/Enau Tanaman Pemanis Alami. Tangerang : PT NUSANTARALESTARI CERIAPRATAMA.

Dewi, Riska. 2016. Analisis Kelayakan Finansial Agroindustry Tahu. Jom Faperta. Vol 3 (1): 1-11.

Gumbira dan Prastiwi, (2005), “Agribisnis Syariah (Manajemen Agribisnis dalam Perspektif Syariah Islam)". Jakarta: Penebar Swadaya.

Herdiyandi. 2016. Analisis Nilai Tambah Agroindustri Tepung Tapioka Di Desa Negaratengah Kecamatan Cineam Kabupaten Tasikmalaya. Jurnal Ilmiah Mahasiswa AGRO INFO GALUH. Vol 2(2): 81-86

Hidayat, Agriananta Fahmi. 2018. Analisa

Kelayakan Finansial Usaha Agroindustry Abon Ikan Di Tanjung Karang Kota Mataram. Jurnal Ilmiah Rekayasa Pertanian Dan Biosistem. Vol 6 (1):69-75.

Hidayati, Nurul. 2017. Analisis Kelayakan Finansial Pengembangan Kelas Alam Terbuka Kebumian Dan Lingkungan Berkonsep Rekreasi Dan Inspirasi Untuk Anak Di Surabaya. Prosiding Seminar Nasional Multi Disiplin Ilmu dan
Call For Papers Unisbank Ke3(Sendi_U3).

Husnan, Suad dan Muhammad, Suwarsono. 2000. Studi Kelayakn Proyek. Edisi 4. UPP AMP YKN. Yogyakarta.

Ibrahim, Yacob. 2009. Studi Kelayakan Bisnis Edisi Revisi. Rineka Cipta.

Juliani, Lusi M. 2019.Analisis Teknis Dan Finansial Usaha Penangkapan Jarring Rampus (Gill Net) Di Pangkalan Pendaratan Ikan (PPI) Cituis Kabupaten Tangerang. Bulletin Ilmiah "Marina" Sosial Ekonomi Kelautan Dan Perikanan. Vol 5 (1): 1-10.

Khotimah, Husnul. 2014. Analisis Kelayakan Finansial Usaha Budidaya Bambu. Jurnal Ilmu Kehutanan. Vol 8 (1): 14-24.

Maesaroh, Ida. 2016. Strategi Pengembangan Agroindustri

Keripik Ubi Kayu. Mimbar Agribisnis Universitas Galuh Ciamis. Vol 1 (3):253-260.

Nasution, Arman Hakim. 2006. Manajemen Industri. Yogyakarta : C.V ANDI OFFSET.

Santoso, Taufan Sukmo. 2008. Analisis Finansial Kerupuk Suka Asih (SKS) Di Pondok Labu, Jakarta Selatan. Skripsi.

Septiawan. 2017. Analisis Biaya, Penerimaan, Pendapatandan R/C Pada Agroindustri Gula Aren. Jurnal Ilmiah Mahasiswa AGROINFOGALUH. Vol 4 (3): 360-365.

Sugiyono. 2012. Metode Penelitian Kuantitatif dan R\&D. Bandung:Alfabeta

Sugandi, Wahyu K. Analisis Kelayakan Ekonomi Mesin Pencacah Rumput Gajah Tipe Reel. Jurnal Agrikultura. Vol 29 (3): 144-149.

Surya, Erdi. 2018. Konservasi Pohon Aren (Arenga Pinnata Merr) Dalam Pemanfaatan Nira Aren Terhadap 
Peningkatan Ekonomi Masyarakat Di Desa Padang Kecamatan Terangun Kabupaten Gayo Lues. BIOnatural. Vol 5 (2): 34-45.

Susilowati, Etty. 2018. Analisis Kelayakan Dan Sensitivitas Industri Kecil Tempe Kopti Semanan Kecamatan Kalideres Jakarta Barat. BISMA (Bisnis dan Manajemen). Vol 10 (2): 102-117.

Tiwa, Ferna. 2016. Evaluasi Kelayakan Proyek Berdasarkan Analisis Kriteria Investasi. Jurnal Sipil Statik.Vol 4 (9): 577-583.
Pasaribu, Maria. 2016. Analisis Kelayakan Finansial Usahatani Kakao Di Kecamatan Bulok Kabupaten Tanggamus. Vol 4 (4): 367-375.

Purnatiyo, Dwinanto. 2014. Analisis Kelayakan Investasi Alat Dna Real Time Thermal Cycler (Rt-Pcr) Untuk Pengujian Gelatin. Jurnal PASTI. Vol 8 (2): 212-226.

Zulfiqoh, Faridha. 2017. Analisis Kelayakan Finansial Usaha Perkebunan Kopi Arabika Di Kebun Kalisat Jampit Wilayah II PTPN XII Bondwoso. Skripsi. 